\title{
Modeling and simulation of the shading effect on the performance of a photovoltaic module in the presence of the bypass diode.
}

\author{
Mohamed Zebiri ${ }^{1, *}$, Mohamed Mediouni ${ }^{1}$, and Hicham Idadoub ${ }^{1}$ \\ ${ }^{1}$ LASIME, National School of Applied Sciences, BP 1136, Agadir, Morocco
}

\begin{abstract}
In photovoltaic renewable energy production systems where production is dependent on weather conditions, maintaining production at a suitable level is more than essential. The shading effect in photovoltaic panels affects the production of electrical energy by reducing it or even causing the destruction of some or all of the panels. To circumvent this problem, among the solutions proposed in the literature we find the use of by-pass diode and anti-return diode to minimize these consequences.In this paper we present a simulation under Matlab-Simulink of the shading effect and we compare the current voltages characteristics (I-V) and power voltage $(\mathrm{P}-\mathrm{V})$ of a photovoltaic system for different irradiations in the presence and absence of diode by -pass. For modeling, we will use the diode model and the Lambert W-function to solve the implicit equation of the output current. This method allows you to analyze the performance of a panel at different shading levels.
\end{abstract}

Key word: Photovoltaics, modeling and simulation, shading, bypass diode, $W$-function of Lambert.

\section{Introduction}

The power produced by a photovoltaic field is the sum of the powers of all the cells composing it [1], but in reality, it is lower there, and that depends on the meteorological conditions. Among the conditions affecting this production we encounter the shading effect that will be presented in this paper. In a field of photovoltaic panels, some modules or cells of a module can be under the shade caused by clouds, trees, buildings, bird droppings.... Moreover, in these conditions, the PV characteristics become more complex and nonlinear they vary with solar insolation and have multiple peaks.

However, it is important to understand and predict them in order to extract as much power as possible. For this reason, over the years, researchers have been studying the characteristics of PV modules and the meteorological factors affecting them. Herin Patel [2] compiled a list of the work done in the study of these characteristics during changes in insolation, temperature or load and their effect on available power.

\footnotetext{
* Corresponding author: m.zebiri@uiz.ac.ma
} 
To study the shading effect we will simulate three modules in series that are subject to different irradiations and we will compare the characteristics obtained in the case of presence of diode bypass and in its absence.

\section{Materials and methods}

\subsection{Photovoltaic equivalent model}

An equivalent circuit can represent a photovoltaic cell. Several models used in the literature and vary in complexity and precision, operating in various conditions. The one-diode model is the most widely used to represent a PV cell, thanks to its simplicity and precision $[1,2,3$, 4] figures one, it consists of a photocurrent source $\left(I_{p h}\right)$, a diode, an internal resistance $\left(R_{s}\right)$ and a shunt resistor $\left(R_{h}\right)$. The model with by-pass diode figure $2,[4,5,6]$ is used to study the effect of shading on the photovoltaic modules using this diode.

\subsubsection{Model without bypass diode}

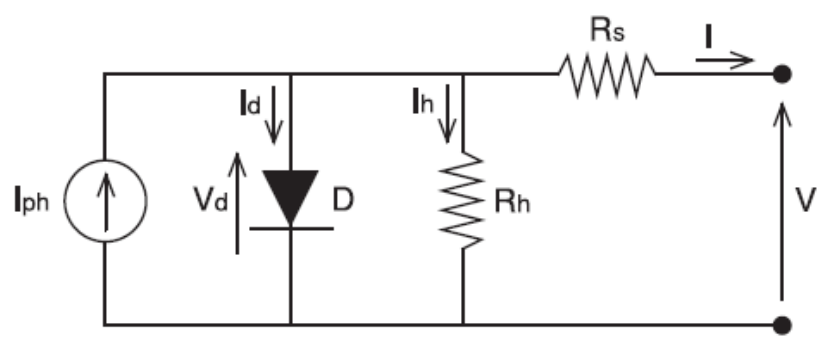

Fig. 1: Electrical model of a PV panel.

$$
\begin{aligned}
& I=I_{p h}-I_{d}-I_{h} \\
& I_{h}=\left(V+I_{s} R_{s}\right) / R_{h} \\
& I_{d}=I_{s a t, d}\left(e^{\left(\frac{V_{d}}{V_{t, d}}\right)}-1\right) \\
& I=I_{p \square}-I_{s a t, d}\left(e^{\left(\frac{V_{d}}{V_{t, d}}\right)}-1\right)-\left(V+I_{s} R_{s}\right) / R_{\square}
\end{aligned}
$$

\subsubsection{Model with bypass diode}

This is the same model as in Figure 1 with a diode $\mathrm{D}_{\mathrm{b}}$ in anti-parallel.

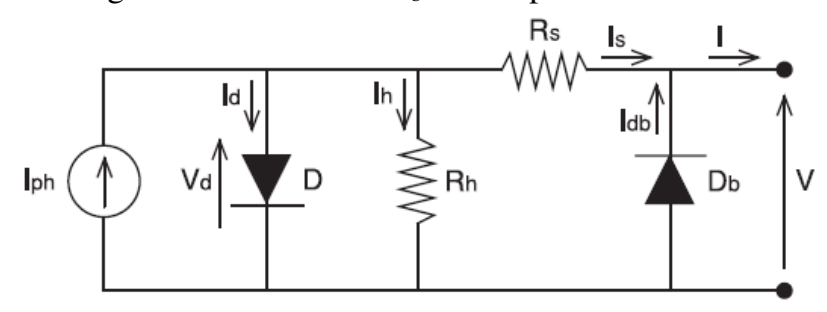

Fig. 2: Electrical model of a PV panel with bypass diode Db [2]. 
In the normal operating mode of the photovoltaic panel, the open circuit voltage is of the order of $0.6 \mathrm{~V}$ for the crystalline cells while in reverse bias operation, the voltages can reach more than $-20 \mathrm{~V}[4,5,6]$

Kirchhoff's law gives the current generated by the PV cell:

$$
\begin{aligned}
& I=I_{p h}-I_{d}-I_{h}+I_{d b} \\
& I_{h}=\left(V+I_{s} R_{s}\right) / R_{h}=\left(V+R_{s}\left(I-I_{d b)}\right) / R_{h}\right. \\
& I_{d b}=I_{s a t, d b}\left(e^{\left(\frac{-V}{V_{t, d b}}\right)}-1\right) \\
& I=I_{p h}-I_{s a t, d}\left(e^{\left(\frac{V_{d}}{V_{t, d}}\right)}-1\right)-\left(V+R_{s}\left(I-I_{d b)}\right) / R_{h}+I_{s a t, d b}\left(e^{\left(\frac{-V}{V_{t, d b}}\right)}-1\right)\right.
\end{aligned}
$$

With $\mathrm{I}_{\mathrm{db}}$, and $\mathrm{V}_{\mathrm{t}}$, are respectively current $\mathrm{db}$ and thermal voltage of the bypass diode.

The system of equations $(5,6,7,8)$ clearly shows that the current I of the PV is a nonlinear and implicit function of the voltage $\mathrm{V}$, the irradiation level and the temperature [5]. Nevertheless, such a non-linear system can be solved in one of the computing environments, such as Matlab. In this way, we can obtain a nonlinear relation between the current I and the voltage V. Such a relation is reported in the equation $(9)[5,7]$ it makes use of the function $\mathrm{W}$ of Lambert of the term $\theta$ of which the value depends on the voltage $\mathrm{V}$ and is reported in equation (10)

$$
I=\frac{R_{S}\left(I_{p \square}+I_{s a t, d}\right)-V}{R_{S \square}+R_{S}}+I_{s a t, d b}\left(e^{\frac{-V}{V_{T, d b}}}-1\right)-\frac{V_{T, d}}{R_{S}} \operatorname{LambertW}(\theta)
$$

With:

$$
\theta=\frac{\left(\mathrm{R}_{\mathrm{h}} \mathrm{R}_{\mathrm{S}} /\left(\mathrm{R}_{\mathrm{h}}+\mathrm{R}_{\mathrm{S}}\right)\right) \mathrm{I}_{\mathrm{sat}, \mathrm{d}} \mathrm{e}^{\left[\mathrm{R}_{\mathrm{h}} \mathrm{R}_{\mathrm{S}}\left(\mathrm{I}_{\mathrm{ph}}+\mathrm{I}_{\mathrm{sat}, \mathrm{d}}\right)+\mathrm{R}_{\mathrm{h}} \mathrm{V} / \mathrm{v}_{\mathrm{T}, \mathrm{d}}\left(\mathrm{R}_{\mathrm{h}}+\mathrm{R}_{\mathrm{S}}\right)\right]}}{\mathrm{V}_{\mathrm{T}, \mathrm{d}}}
$$

\subsection{Partial shading and bypass diodes}

In nature the uniform irradiation is not always satisfied because of the shadows of buildings or trees, the fluctuation of the atmosphere, clouds and variations of the solar angle and the loss of power occurs precisely by the effect of shading. The impact of this effect is reduced by several factors including the bypass diode. In practice, a module contains bypass diodes to prevent damage due to reverse bias on shaded cells. These diodes are placed in antiparallel with a group of 18 cells in general.

The bypass diode will start driving as soon as a shaded cell is reverse biased. It allows the current from the non-shaded modules to shunt around the shaded cells through this diode thus protecting this cell group and limit the shading effect to only the neighboring group of cells protected by the same bypass diode. The effect of shading on the output of a PV module is non-linear because a small amount of shadow on part or the entire module can result in a significant reduction in output power.

If the generated current $\left(\mathrm{I}_{\mathrm{ph}}\right)$ of a module decreases to a level lower than the current generated by all the modules in series, the bypass diode limits the reverse voltage to a value lower than the breakdown voltage of the PV cells. In other words, and as illustrated in figure 5, the third bypass diode begins to operate when equation (11) is satisfied.[8]

$$
\mathrm{I}_{\mathrm{pva}}>\mathrm{I}_{\mathrm{ph}} \text { (i) }
$$




\subsection{Simulation}

In our simulation we used three modules (Kyocera KC130GT figure 4) connected in series figures $3 \mathrm{a}$ and $3 \mathrm{~b}$. The modules receive different irradiations. At first, we conduct our simulation without bypass diode figure $3 \mathrm{a}$, and then we use a bypass diode for each module figure $3 b$.

The numbered modules 1, 2, 3 are illuminated first by an irradiation of $1000 \mathrm{w} / \mathrm{m}^{2}$ each in both cases, i.e. without shadow, then they will be illuminated respectively by following variants irradiations between $\left(1000 \mathrm{w} / \mathrm{m}^{2}, 600 \mathrm{w} / \mathrm{m}^{2}\right.$ and $\left.200 \mathrm{w} / \mathrm{m}^{2}\right)$ in both configurations, see table 1 .

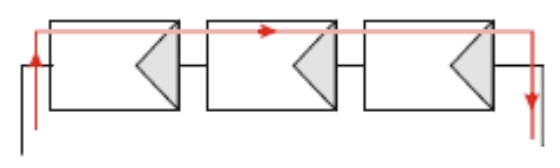

Fig. 3a: Three PV modules connected in series without bypass diode.

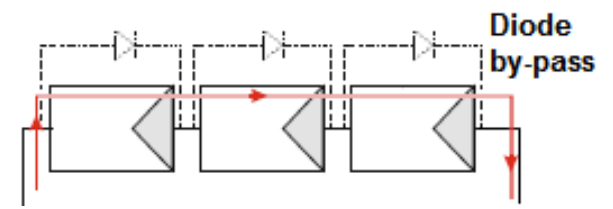

Fig. 3b: Three PV modules connected in series with bypass diode.

\begin{tabular}{l|l}
\hline Electrical Performance under Standard Test Conditions $\left({ }^{*} \mathrm{STC}\right)$ \\
\hline Maximum Power (Pmax) & $130 \mathrm{~W}(+10 \% /-5 \%)$ \\
\hline Maximum Power Voltage (Vmpp) & $17.6 \mathrm{~V}$ \\
\hline Maximum Power Current (Impp) & $7.39 \mathrm{~A}$ \\
\hline Open Circuit Voltage (Voc) & $21.9 \mathrm{~V}$ \\
\hline Short Circuit Current (Isc) & $8.02 \mathrm{~A}$ \\
\hline Max System Voltage & $600 \mathrm{~V}$ \\
\hline Temperature Coefficient of Voc & $-8.21 \times 10^{-2} \mathrm{~V} /{ }^{\circ} \mathrm{C}$ \\
\hline Temperature Coefficient of IsC & $3.18 \times 10^{-3} \mathrm{~A} /{ }^{\circ} \mathrm{C}$ \\
\hline 'STC
\end{tabular}

Fig. 4: Kyocera KC130GT module specifications

Table 1 Different simulation scenarios in the presence and absence of bypass diode.

\begin{tabular}{|l|c|c|c|}
\hline & $\begin{array}{c}\text { Irradiation in w/m } / \mathrm{m}^{2} \text { of } \\
\text { Module } 1\end{array}$ & $\begin{array}{c}\text { Irradiation in } \mathrm{w} / \mathrm{m}^{2} \text { of } \\
\text { Module } 2\end{array}$ & $\begin{array}{c}\text { Irradiation in w/m } \mathrm{m}^{2} \text { of } \\
\text { Module } 3\end{array}$ \\
\hline $1^{\circ}$ scenario & 1000 & 1000 & 1000 \\
\hline $2^{\circ}$ scenario & 1000 & 1000 & 200 \\
\hline $3^{\circ}$ scenario & 1000 & 600 & 200 \\
\hline
\end{tabular}




\section{Results and discussion}

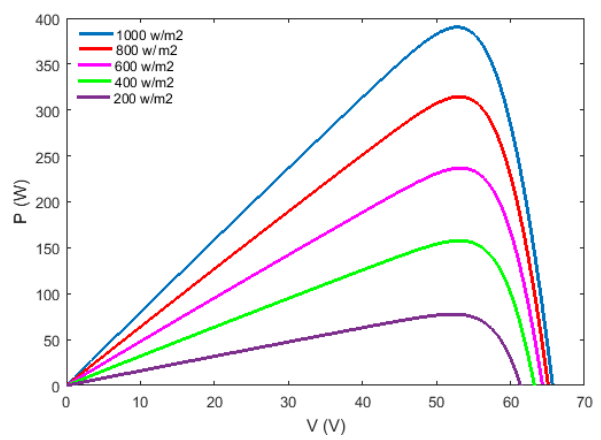

Fig. 5a: P-V Characteristics of three PV cells with different irradiance without bypass diode.

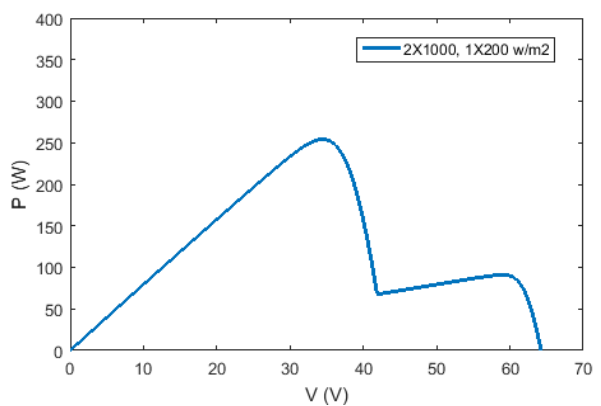

Fig. 6a: P-V Characteristics of three PV cells with different irradiance with bypass diode.

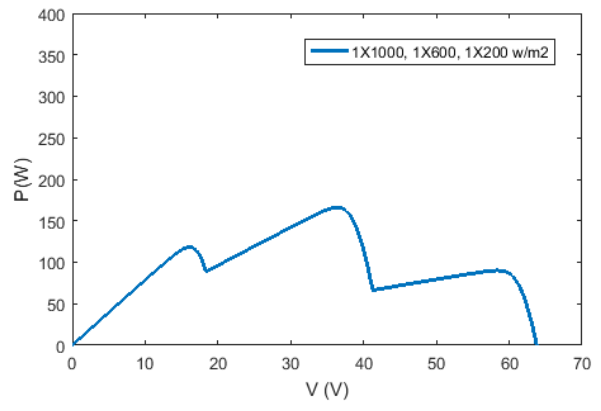

Fig. 6c: P-V Characteristics of three PV cells with different irradiance with bypass diode.

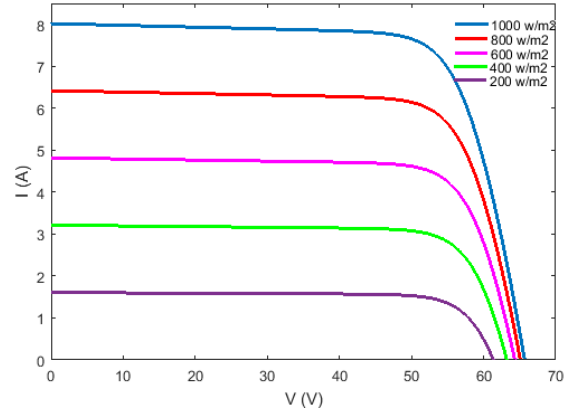

Fig. 5b: I-V Characteristics of three PV cells with different irradiance without bypass diode.

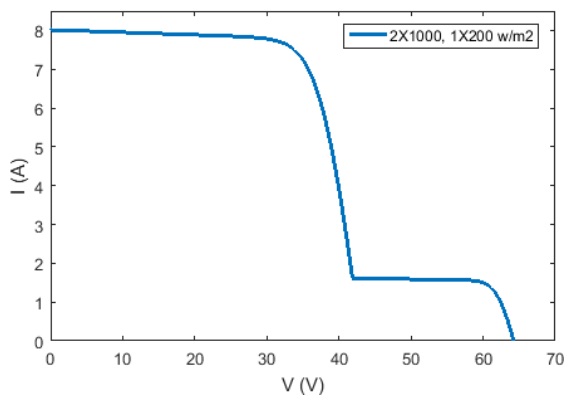

Fig. 6b: I-V Characteristics of three PV cells with different irradiance with bypass diode.

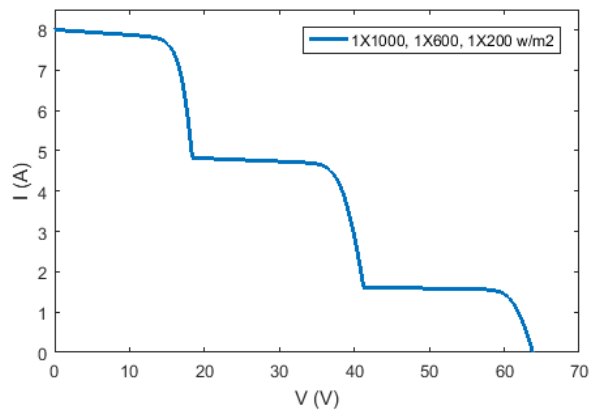

Fig. 6d: I-V Characteristics of three PV cells with different irradiance with bypass diode.

Figures $5 \mathrm{a}$ and $5 \mathrm{~b}$ show the characteristics $(\mathrm{P}-\mathrm{V})$ and $(\mathrm{I}-\mathrm{V})$ of the PV modules with variable illumination but the same for all the modules, at constant temperature in the presence and absence of the bypass diode. From the graph we find that as the irradiation decreases, the current and the output voltage also decrease, which implies the decrease of the output power.

Without a bypass diode, the output power of the three modules is severely affected and is equivalent to the power of the least lighted module. We notice that the shading causes a significant degradation of the power output. 
On the other hand, in the presence of a bypass diode the power is maintained at higher levels and we observe global and local maximum peaks present in the characteristic (PV) figure $6 \mathrm{a}$ and $6 \mathrm{~b}$ and the power produced is greater figure $7 \mathrm{a}$ than in the absence of the bypass diode figure $7 \mathrm{~b}$. The figure 8 shows the path taken by the current produced by the modules in full sunlight. The diode becomes active and in this state, its impedance becomes lower than that of the shaded module and the current of the other modules shunts around the module that through this diode. This prevents the unshaded modules from forcing a current against the polarized state in inverse of the cells of the shaded module and therefore, overheating (hot spot) is avoided for the module under shading [9].

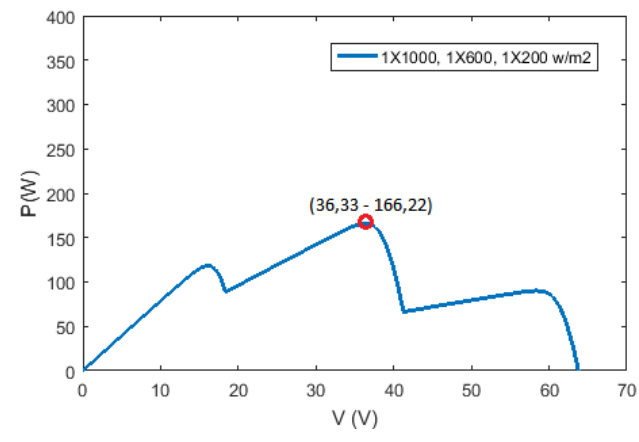

Fig. 7a: Characteristic $(\mathrm{P}-\mathrm{V})$ at different illuminations in the presence of bypass diode.

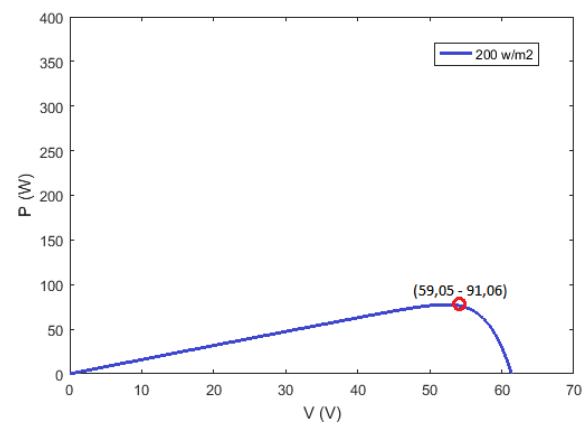

Fig. 7b: Characteristic (P-V) at the same illuminations as in 7 a but without a bypass diode.

In figure 7 we compare the maximum power point of the characteristic $(\mathrm{P}-\mathrm{V})$ with bypass diode figure $7 \mathrm{a}$ and without bypass diode figure $7 \mathrm{~b}$. We note that with a bypass diode the maximum power is $166.22 \mathrm{w}$ while without a bypass diode it is only $91.06 \mathrm{w}$. Because of the presence of a bypass diode, the non shaded module can still produce full power and PV system gets higher power output.

We can say that a bypass diode :

1 Shunte the current of the module around the shaded cells figure 8 ;

2 Protects the solar cells in the modules against the formation of hot spots ;

3 Reduces the reverse voltage through the shaded cells in the modules

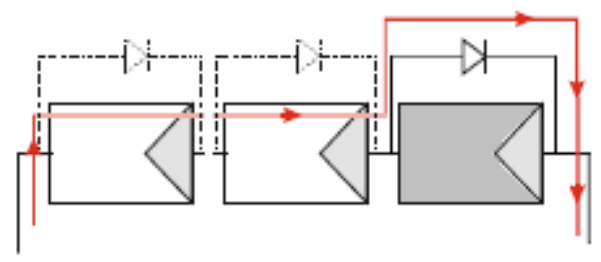

Fig. 8: The path taken by the current in case of shading.

The results obtained by our simulations are the same obtained by works in the literature Table 3 gives a list of some works.

Table 3: List of some works on the shading effect and by-pass diode.

\begin{tabular}{|l|l|}
\hline Auteur & Modèle \\
\hline K. Matter [3] & A diode with Simulink \\
G. Petrone [5] & Analytical with Lambert W-function \\
J. D. Bastidas-Rodríguez [7] & A diode with Lambert W-function \\
R. Ramabadran [10] & A Matlab Analytical Diode \\
E. Díaz-Dorado [11] & Overlapped and non-overlapped bypass diodes \\
A. Mermoud [12] & Bypass diode analysis \\
\hline
\end{tabular}




\section{Conclusion}

In this work, we studied the effect of different shading conditions on the output power of PV modules. We used Matlab / Simulink to perform our simulations and used the Kyocera KC130GT module specifications. The results obtained under partial shading conditions clearly show that the performance of the panels varies and strongly depends on these conditions. So note that in the presence of the bypass diode the characteristic (P-V) has several peaks, the number of which depends on the illumination values received by the modules under shading. This feature contains a global spike and other locales. While in the absence of this diode, we have one and the only whatever the insolation of the modules and this peak is the maximum power produced by the least lighted module. We conclude that the existence of these diodes improves the value of the output power in cases where one of the modules is in partial or full shading conditions. The study of the characteristics of a photovoltaic field in the event of shading and creating a database of these characteristics will be used to make adequate decisions and in time to prevent probable failures and thus to ensure a better maintenance intervention.

\section{References}

1 L. Bun, Détection et localisation de défauts pour un système PV, tel-00647189v1 (2011)

2 H. Patel and V. Agarwal, Senior Member IEEE, IEEE 23, ( march 2008)

3 K. Matter, H. J. El-Khozondar, R. J. El- Khozondar, T. Suntio, IRJET, 02 Issue 02, (2015)

4 G. Notton, I. Caluianu, I. Colda et S. Caluianu,. R E R 1349 - 62, (2010)

5 G. Petrone, G. Spagnuolo, M. Vitelli. S E M \& S C 9, 1652-1657, (2007)

6 M.L. Orozco-Gutierrez, J.M. Ramirez-Scarpetta, G. Spagnuolo, C.A. Ramos-Paja. R E 55, 417 - 427, (2013)

7 J. D. Bastidas-Rodríguez, L. A. Trejos-Grisales, D. González-Montoya, C. A. RamosPaja, G. Petrone, G. Spagnuolo, E P S R 155 67-79, (2018)

8 M. Seyedmahmoudian, S. Mekhilef, R. Rahmani, Y. Rubiyah, E. T. Renani, Energies, 6, 128-144, (2013)

9 P. Bulanyi, R. Zhang, The 52nd Annual Conference of the Australian Solar Council (Solar2014)

10 R. Ramabadran, R. Gandhi Salai, B. Mathur, J S D, 2, No. 3, (11/2009)

11 E. Díaz-Dorado, A. Suárez-García, C. Carrillo, and J. Cidrás, (SPEEDAM 2010 )

12 A. Mermoud, T. Lejeune, (25th European Photovoltaic Solar Energy Conference. 2010) 